B. Anggun Hilendri L. : Akuntabilitas Koperasi Melalui Laporan Keuangan

\title{
AKUNTABILITAS KOPERASI MELALUI LAPORAN KEUANGAN
}

\author{
B. Anggun Hilendri Lestari \\ Fakultas Ekonomi Dan Bisnis Universitas Mataram \\ hilendria@unram.ac.id
}

\begin{abstract}
Cooperatives are one of three types of business entities that support the Indonesian economy in addition to State-Owned Enterprises (BUMN) and Private-Owned Enterprises (BUMS). The development and growth of cooperatives in Indonesia is endeavored to continue to synergize with the duties of cooperatives in holding their institutions accountable to the government and the development of their business to their members. This is a form of implementation of cooperative accountability in which cooperatives must be able to manage services and be informed to interested parties in the form of financial statements. The purpose of this study was to find out how the accountability of Karya Mandiri Selong cooperatives through cooperative financial statements that have been prepared. Accountability of Karya Mandiri Selong cooperatives through the preparation of financial reports is not optimal as indicated by the preparation of financial statements in the form of monthly reports containing reports on loans or accounts receivable and deposits from cooperative customers. This is because the management's understanding of financial accounting standards is still lacking. The hope is for the future Karya Mandiri Selong cooperatives can compile financial reports in accordance with financial accounting standards so that accountability is maintained and member trust increases.
\end{abstract}

Key Words: accountability, financial statements

\section{PENDAHULAN}

Koperasi adalah satu dari tiga jenis bentuk badan usaha yang menyokong perekonomian Indonesia selain Badan Usaha Milik Negara (BUMN) dan Badan Usaha Milik Swasta (BUMS). Namun demikian, berbeda dari kedua jenis bentuk badan usaha lainnya, Koperasi memiliki karteristik utama yang 
khas. Undang-undang Republik Indonesia tahun 1992 tentang Perkoperasian menyatakan bahwa karakteristik utama koperasi yang membedakannya dengan badan usaha lain adalah bahwa anggota koperasi memiliki identitas ganda (the dual identity of the member), yaitu anggota sebagai pemilik dan sekaligus pengguna jasa koperasi (user own oriented firm).

Karakteristik utama koperasi yang khas tersebut, mengarahkan koperasi untuk mencapai tujuan yang yang khas pula, sebagaimana dinyatakan dalam Undang-Undang Republik Indonesia Nomor 25 tahun 1992 tentang Perkoperasian dalam Pasal 3 yang menyatakan bahwa Koperasi bertujuan memajukan kesejahteraan anggota pada khususnya dan masyarakat pada umumnya serta ikut membangun tatanan perekonomian nasional dalam rangka mewujudkan masyarakat yang maju, adil, dan makmur berlandaskan Pancasila dan Undang-Undang Dasar 1945.

Perkembangan dan pertumbuhan koperasi di Indonesia diupayakan agar terus bersinergi dengan tugas-tugas koperasi dalam mempertanggung jawabkan kelembagaannya kepada pemerintah maupun perkembangan usahanya kepada anggotanya. Sesuai dengan perkembangan koperasi dalam melaporkan laporan keuangannya, kini telah dikeluarkan Standar Akuntansi Keuangan No.27 tentang Akuntansi Perkoperasian yang telah mendapat revisi tahun 1998, dan Reformat tahun 2007 serta adanya Standar Akuntansi 


\section{B. Anggun Hilendri L. : Akuntabilitas Koperasi Melalui Laporan Keuangan}

Keuangan Entitas Tanpa Akuntabilitas Publik (SAK ETAP) yang baru dikeluarkan oleh Ikatan Akuntan Publik pada Mei 2009.

Penerapan standar akuntasi perkoperasian ini diharapkan dapat memberi gambaran kinerja manajemen koperasi di masa lalu dan prospek di masa yang akan datang, sehingga dapat dipercaya dan diandalkan baik oleh pengurus maupun oleh anggota koperasi dan pihak eksternal yang memiliki kepentingan terhadap koperasi tersebut. Hal tersebut merupakan bentuk pelaksanaan akuntabilitas koperasi yang mana koperasi harus mampu mengelola jasa serta diinformasikan kepada pihak-pihak yang berkepentingan dalam bentuk laporan keuangan, dimana informasi mengenai aktiva, kewajban, aktiva bersih, dan informasi mengenai hubungan diantara unsurunsur tersebut disampaikan. Laporan yang disusun tersebut juga harus menyajikan secara terpisah aktiva bersih, baik terikat maupun tidak terikat penggunaannya. Hasil pengelolaan sumber daya koperasi akan dipertanggungjawabkan melalui penyajian laporan keuangan.

Meskipun seperti itu harapan pemerintah, baru-baru ini Kementerian Koperasi Republik Indonesia mengeluarkan surat keputusan yang menjelaskan bahwa sebanyak 159 koperasi dibubarkan di kabupaten/kota di NTB. Masingmasing 10 koperasi di Kabupaten Bima, 7 koperasi di Kabupaten Dompu, 53 koperasi di Kabupaten Lombok Tengah, 32 koperasi di Kabupaten Lombok 
Timur dan terbanyak 57 koperasi di Kota Mataram, karena dari 4.026 jumlah koperasi yang tersebar di kabupaten/kota di NTB hampir 50 persen yang dinyatakan tidak aktif. Dari 50 persen yang aktif inipun, baru 40 persen yang melakukan RAT, hingga Agustus 2017, padahal, RAT adalah amanat AD/ART koperasi yang harus dilaksanakan tanpa tawaran (https://www.suarantb.com).

Berdasarkan penjelasan tersebut, penelitian ini akan dilakukan pada salah satu koperasi di kabupaten Lombok Timur tepatnya di Koperasi Simpan Pinjam (KSP) KARYA MANDIRI Selong. Pemilihan lokasi penelitian ini dikarenakan koperasi-koperasi di Lombok Timur menunjukkan perkembangan yang kurang terkait akuntabilitasnya dalam melakukan RAT setiap tahunnya rata-rata pencapaian sekitar $33 \%$. Hal ini disebabkan oleh kurangnya kesadaran oleh gerakan koperasi itu sendiri maupun belum optimalnya pembinaan yang dilakukan oleh Dinas terkait. Tujuan penelitian ini adalah untuk mengetahui bagaimana akuntabilitas KSP Karya Mandiri Selong melalui laporan keuangan koperasi yang telah disusun. 


\section{B. Anggun Hilendri L. : Akuntabilitas Koperasi Melalui Laporan Keuangan}

Koperasi didefinisikan sebagai " badan usaha yang beranggotakan orang-orang atau badan hukum koperasi dengan melandaskan kegiatan berdasarkan prinsip-prinsip koperasi sekaligus sebagai grakan ekonomi rakyat yang berdasarkan atas asas kekeluargaan". Pengertian ini disusun tidak hanya berdasarkan pada konsep koperasi sebagai organisasi ekonomi dan social tetapi secara lengkap telah mencerminkan norma-norma/ kaidah-kaidah yang berlaku bagi bangsa Indonesia. (Kusnadi, 2005). Kusnadi (2005) menjelaskan jenis-jenis koperasi ada 4 yaitu:

1. Koperasi Berdasarkan Jenisnya ada 4, yaitu:

a. Koperasi Produksi (Koperasi Produksi melakukan usaha produksi atau menghasilkan barang)

b. Koperasi konsumsi (Koperasi Konsumsi menyediakan semua kebutuhan para anggota dalam bentuk barang)

c. Koperasi Simpan Pinjam (Koperasi Simpan Pinjam melayani para anggotanya untuk menabung dengan mendapatkan imbalan)

d. Koperasi Serba Usaha (Koperasi Serba Usaha (KSU) terdiri atas berbagai jenis usaha)

2. Berdasarkan Tingkatannya

a. Koperasi Primer (Koperasi primer merupakan koperasi yang beranggotakan orang-orang) 
b. Koperasi sekunder (Koperasi sekunder merupakan koperasi yang beranggotakan beberapa koperasi)

3. Jenis koperasi berdasarkan fungsinya

a. Koperasi Konsumsi (didirikan untuk memenuhi kebutuhan umum seharihari para anggotanya)

b. Koperasi Jasa (adalah untuk memberikan jasa keuangan dalam bentuk pinjaman kepada para anggotanya)

c. Koperasi Produksi (Bidang usahanya adalah membantu penyediaan bahan baku, penyediaan peralatan produksi, membantu memproduksi jenis barang tertentu serta membantu menjual dan memasarkannya hasil produksi tersebut).

Prinsip koperasi telah dicantumkan dalam UU No. 12 Tahun 1967 dan UU No. 25 Tahun 1992. Berdasarkan UU No. 25 Tahun 1992, Prinsip koperasi dinyatakan sebagai berikut Kusnadi (2005):

1. Keanggotaan bersifat terbuka dan sukarela

2. Pengelolaan dilakukan secara demokratis

3. Pembagian sisa hasil usaha dilakukan secara sdil sebanding dengan besarnya jasa usaha masing-masing anggota

4. Pemberian balas jasa yang terbatas terhadap modal

5. Kemandirian 


\section{B. Anggun Hilendri L. : Akuntabilitas Koperasi Melalui Laporan Keuangan}

\section{Pendididkan perkoperasian}

7. Kerjasama antarkoperasi

Terkait dengan akuntabilitas koperasi dapat diwujudkan melalui penyusunan laporan keuangan. Akuntabilitas adalah kemampuan memberi jawaban kepada otoritas yang lebih tinggi atas tindakan seseorang/sekelompok orang terhadap masyarakat luas dalam suatu organisasi (Rasul, 2003).

Akuntabilitas merupakan perwujudan kewajiban seseorang atau unit organisasi untuk mempertanggungjawabkan pengendalian dan pengelolaan sumber daya dan pelasanaan kebijakan yang dipercayakan kepadanya dalam rangka pencapaian tujuan yang telah ditetapkan melalui media pertanggungjawaban secara periodik (Nurlailah dkk, 2004 dalam Nikita, 2018). Mengingat koperasi merupakan entitas yang menggunakan sumber daya yang dipercayakan oleh anggota kepada pengurus koperasi, maka koperasi membutuhkan laporan keuangan yang dapat dipertanggungjawabkan.

Laporan keuangan adalah laporan yang berisi informasi sebuah entitas (Jusuf, 2012). Laporan keuangan merupakan media komunikasi dan pertanggungjawaban antara perusahaan dan para pemiliknya atau pihak lain. Tujuan laporan keuangan dalam SAK ETAP paragraf 2.1 adalah menyediakan informasi posisi keuangan, kinerja keuangan, dan laporan arus kas suatu entitas yang bermanfaat bagi sejumlah besar pengguna dalam pengambilan 
keputusan ekonomi oleh siapapun yang tidak dalam posisi dapat meminta laporan keuangan khusus untuk memenuhi kebutuhan informasi tertentu. Dalam memenuhi tujuannya, laporan keuangan juga menunjukkan apa yang telah dilakukan manajemen (stewarship) atau pertanggungjawaban manajemen atas sumber daya yang dipercayakan kepadanya. Laporan keuangan entitas dan informasi-informasi yang disajikan dalam setiap laporan keuangan sesuai yang diatur dalam Standar Akuntansi Keuangan Entitas Tanpa Akuntabilitas Publik adalah:

a. Neraca

Neraca menyajikan aset, hutang, dan ekuitas suatu entitas pada suatu tanggal tertentu-akhir periode pelaporan (SAK ETAP paragrap 4.1).

Neraca minimal mencakup pos-pos berikut: 1) Kas dan setara kas, 2) Piutang usaha dan piutang lainnya, 3) Persediaan, 4) Properti investasi, 5) Aset tetap, 6) Aset tidak berwujud, 7) Utang usaha dan utang lainnya, 8) Aset dan hutang pajak, 9) Hutang diestimasi, dan 10) Ekuitas

b. Laporan laba rugi

Laporan laba rugi memasukkan semua pos penghasilan dan beban yang diakui dalam suatu periode kecuali SAK ETAP mensyaratkan lain (SAK ETAP paragrap 5.2). Laporan laba rugi minimal mencakup pos-pos sebagai berikut: 1) Pendapatan, 2) Beban keuangan, 3) Bagian laba atau rugi dari 


\section{B. Anggun Hilendri L. : Akuntabilitas Koperasi Melalui Laporan Keuangan}

investasi yang menggunakan metode ekuitas, 4) Beban pajak, dan 5) Laba atau rugi neto

c. Laporan perubahan ekuitas yang menunjukkan: (1) Seluruh perubahan dalam ekuitas, atau (2) Perubahan ekuitas selain perubahan yang timbul dari transaksi dengan pemilik dalam kapasitasnya sebagai pemilik.

d. Laporan Arus Kas

Setara kas adalah investasi jangka pendek dan sangat likuid yang dimiliki untuk memenuhi komitmen kas jangka pendek, bukan untuk tujuan investasi atau lainnya (SAK ETAP paragraf 7.2).

Entitas menyajikan laporan arus kas yang melaporkan arus kas untuk suatu periode dan mengklasifikasikan menurut aktivitas operasi, aktivitas investasi, dan aktivitas pendanaan.

e. Catatan atas laporan keuangan yang berisi ringkasan kebijakan akuntansi yang signifikan dan informasi penjelasan lainnya. Catatan atas laporan keuangan memberikan penjelasan naratif atau rincian jumlah yang disajikan dalam laporan keuangan dan informasi pos-pos yang tidak memenuhi kriteria pengakuan dalam laporan keuangan (SAK ETAP paragraf 8.1). Entitas yang laporan keuangannya mematuhi SAK ETAP harus membuat suatu pernyataan dan secara penuh (explicit and unreserved statement) atas kepatuhan tersebut dalam catatan atas laporan keuangan. Laporan 
keuangan tidak boleh menyatakan mematuhi SAK ETAP kecuali jika mematuhi semua persyaratan dalam SAK ETAP. Karakteristik kualitatif informasi dalam laporan keuangan yaitu:

a. Dapat dipahami

Kualitas penting informasi yang disajikan dalam laporan keuangan adalah kemudahan untuk dipahami oleh pengguna

b. Relevan

Informasi keuangan harus relevan dengan kebutuhan pengguna untuk proses pengambilan keputusan dan membantu dalam melakukan evaluasi

c. Materialitas

Informasi yang disampaikan dalam jumlah yang cukup material. Pos-pos yang jumlahnya material disajikan tersendiri dalam laporan keuangan sedangkan yang jumlahnya tidak material dapat digabungkan sepanjang memiliki sifat atau fungsi yang sejenis.

d. Keandalan

Informasi memiliki kualitas andal jika bebas dari kesalahan ,aterial dan bias jika dimaksudkan untuk mempengaruhi pembuatan suatu keputusan atau kebijakan untuk tujuan mencapai suatu hasil tertentu.

e. Substansi mengungguli bentuk 


\section{B. Anggun Hilendri L. : Akuntabilitas Koperasi Melalui Laporan Keuangan}

Transaksi dan peristiwa dicatat dan disajikan sesuai dengan substansi dan realitas ekonomi.

f. Pertimbangan sehat

Pertimbangan sehat mengandung unsur kehati-hatian pada saat melakukan pertimbangan yang diperlukan dalam kondisi ketidakpastian.

g. Dapat dibandingkan

Pengguna harus dapat membandingkan laporan keuangan antar periode untuk mengidentifikasi kecenderungan posisi dan kinerja keuangan

h. Tepat waktu

Informasi dalam laporan keuangan harus dapay mempengaruhi keputusan ekonomi para penggunanya. Tepat waktu meliputi penyediaan informasi laporan keuangan dalam jangka waktu pengambilan keputusan

i. Keseimbangan antara biaya dan manfaat

Evaluasi biaya dan manfaat merupakan proses pertimbangan yang substansial. Dalam evaluasi manfaat dan biaya, entitas harus memahami bahwa manfaat informasi mungkin juga manfaat yang dinikmati oleh pengguna eksternal. 
Jenis penelitian ini adalah penelitian deskriptif. Metode deskriptif merupakan metode yang bertujuan untuk menggambarkan suatu keadaan sebenarnya secara sistematis berdasarkan fakta-fakta di lapangan. Adapun lokasi penelitian terletak di Kota Selong Kabupaten Lombok Timur. Responden dalam penelitian ini adalah pengurus dan pengawas koperasi. Teknik yang digunakan terdiri dari wawancara, observasi, dokumentasi, dan studi pustaka dengan jenis data yang dikumpulkan berupa data kualitatif dan kuantitatif yang bersumber dari data primer dan sekunder.

Teknik analisis yang dilakukan analisis deskriptif kualitatif. Teknik ini dibutuhkan dalam penelitian ini dikarenakan mempunyai tujuan untuk memberikan gambaran akuntabilitas KSP Karya Mandiri melalui laporan keuangan. Analisis ini juga merupakan suatu analisis yang tidak dinyatakan dalam dalam perhitungan kuantitatif melainkan mengolah dan mengungkapkan serta menguraikan masalah satu per satu sesuai dengan tujuan penelitian, yang berupa pernyataan dan kesimpulan. Adapun tahapannya sebagai berikut:

a. Langkah Permulaan: Proses Pengolahan

1. Editing

Pada tahap ini kita melakukan pemeriksaan terhadap jawaban-jawaban informan, hasil observasi, dokumen-dokumen, memilih foto, dan 


\section{B. Anggun Hilendri L. : Akuntabilitas Koperasi Melalui Laporan Keuangan}

catatan lainnya. Tujuannya adalah untuk penghalusan data selanjutnya yaitu perbaikan kalimat dan kata, memberi keterangan tambahan, membuang keterangan berulang-ulang atau tidak penting, menerjemahkan ungkapan setempat ke Bahasa Indonesia, termasuk juga mentranskrip rekaman wawancara.

2. Klasifikasi

Pada tahap ini kita menggolong-golongkan jawaban dan data lainnya menurut kelompok wariabelnya. Selanjutnya, diklasifikasikan lagi menurut indikator tertentu seperti yang ditetapkan sebelumnya. Pengelompokan ini sama dengan menumpuk-numpuk data sehingga akan mendapat tempat di dalam kerangka (outline) laporan yang telah ditetapkan sebelumnya.

3. Memberi Kode

Pada tahap ini kita melakukan pencatatan judul singkat (menurut indikator dan variabelnya), serta memberikan catatan tambahan yang dinilai perlu dan dibutuhkan, sedangkan tujuannya agar memudahkan kita menemukan makna tertentu dari setiap tumpukan data serta mudah menempatkannya di dalam outline laporan.

b. Langkah Lanjut: Penafsiran 
Penafsiran merupakan langkah terakhir dalam analisis data. Pada tahap ini, data yang sudah diberi kode kemudian diberi penafsiran. Kita melakukan analisis data dengan memperkaya informasi melalui analisis komparasi (perbandingan) sepanjang tidak menghilangkan konteks aslinya. Hasilnya adalah penerapan gambar tentang situasi dan gejala dalam bentuk pemaparan naratif.

Validasi data dilakukan triangulasi, meliputi triangulasi metode, sumber data dan data itu sendiri.

a. Triangulasi metode dengan cara mengkombinasikan metode wawancara dengan observasi langsung.

b. Triangulasi sumber dengan cara menggunakan informan yang berbeda untuk melakukan cross check dan penelusuran data sekunder.

c. Triangulasi data dengan mengembalikan kompilasi data serta hasil interpretasi data kepada informan, untuk mendapatkan masukan, koreksi atas kesalahan dan menghindarkan subyektivitas peneliti.

\section{HASIL DAN PEMBAHASAN}

\section{Gambaran Umum Koperasi}




\section{B. Anggun Hilendri L. : Akuntabilitas Koperasi Melalui Laporan Keuangan}

KSP " KARYA MANDIRI" Selong didirikan pada tannggal 10 oktober 2011 dengan nama Koperasi Simpan Pinjam (KSP) "KARYA MANDIRI" yang berlokasi di Jl. Haji Hasyim As'ary Lendang Bedurik, Selong, koperasi ini pertama kali dirintis oleh Bpk Ismail selaku Ketua Pimpinana saat ini dan Bpk Zuhri selaku Manajer.Sejak pertama berdirinya koperasi ini memiliki 2 wilayah penagihan (Resot/Unit ) dimana yang menjalankan hanya pak Ismail dan Pak Zuhri,seiring berjalannya waktu Resotnya semakin bertambah hingga Ketua Pimpinana merekrut beberapa karyawan,yaitu stap kasir,rekap,pekarja lapangan, dan pengawas.Pada tahun 2013 anggota berkembang sangat pesat hingga wilayah penagihan (Unit) sampai 5 wilayah yaitu Pancor,Tanjung teros,Masbagik,Labuan Haji,dan Rempung hingga saat itu anggota terus bertambah dan sampai saat ini tahun 2018 KSP "KARYA MANDIRI" memiliki 10 wilayah yaitu, Pacor, Tanjung Teros,Masbagik,Labuan Haji,Rempung, Sakra, jerowaru, keruak, yang jumlah anggotanya mencapai 1.302 orang sampai dengan awal tahun 2018, dengan rincian jumlah anggota wanita 702 orang dan anggota laki-laki 600 orang.

Jumlah anggota tahun ini mengalami peningkatan sebanyak 35 orang dibanding tahun 2017 yang tercatat sebanyak 1.267orang..Sampai saat ini KSP "KARYA MANDIRI" mengalami peningkatan pendapatan dari tahun ke tahun. KSP "KARYA MANDIRI" Selong beberapa kali pernah pindah lokasi karena KSP 
"KARYA MANDIRI" Selong belum mempunyai gedung sendiri melaikan menyewa gedung dan sampai saat ini masih belum punya gedung sendiri. Tujuan pendirian atau rencana kerja KSP "KARYA MANDIRI" Selong di bidang usaha antara lain:

1. Mengembangkan dan meningkatkan pelayanan kegiatan Unit Simpan Pinjam kepada anggota dengan memberikan pinjaman sesuai persyaratan dan penilaian pengurus, dengan jangka waktu maksimal 40 hari dan besar jasa bunga pinjaman yang dikenakan $5 \%$.

2. Mendorong para anggota untuk hidup hemat, karena didorong untuk menabung.

3. Membuka lapangan pekerjaan bagi masyarakat.

\section{Penyusunan Laporan Keuangan Pada KSP "KARYA MANDIRI" Selong}

Proses akuntansi yang dilakukan oleh KSP "KARYA MANDIRI" Selong dalam pembuatan Laporan Keuangan masih secara manual. Adapun bagan proses penyusunan laporan keuangan pada KSP "KARYA MANDIRI" Selong sebagai berikut :

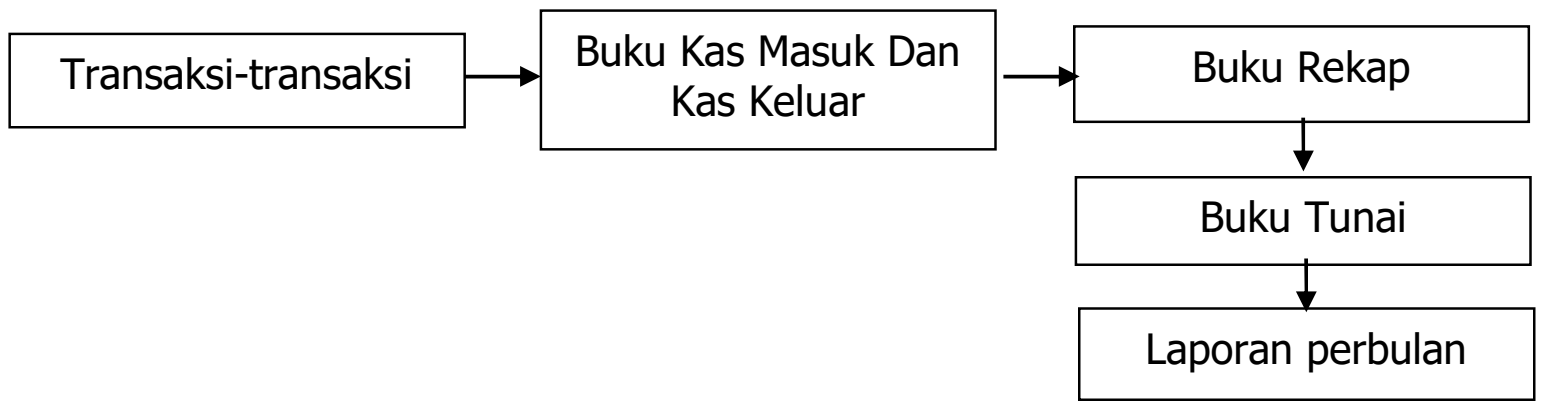


Jika kita melihat bagan tersebut, tampak bahwa KSP "KARYA MANDIRI" Selong menyusun laporan keuangan tidak seperti yang seharusnya atau sesuai dengan SAK ETAP yang telah ditetapkan. Adapun siklus akuntansi yang seharusnya sebagai berikut:

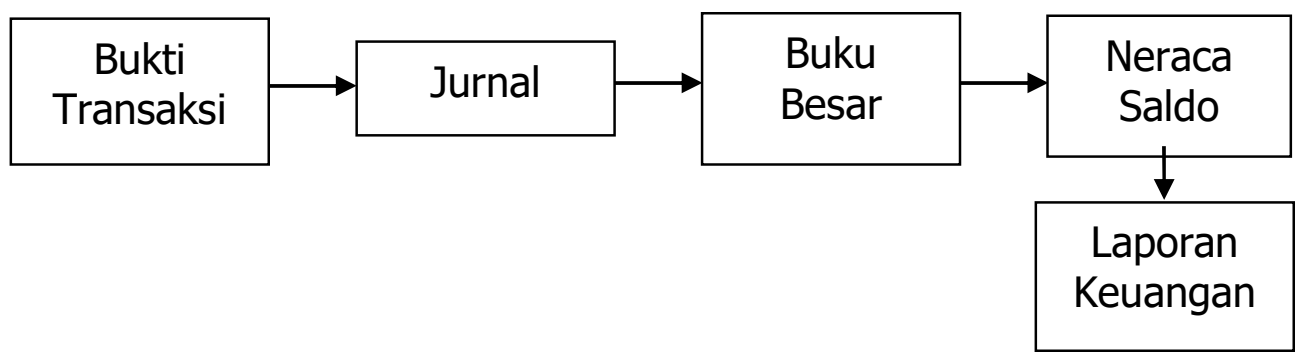

Jadi, KSP "KARYA MANDIRI" Selong tidak membuat buku besar, neraca saldo sampai dengan laporan keuangan. Laporan keuangan koperasi berupa laporan per bulan berisi laporan pinjaman atau piutang dan setoran nasabah koperasi. Jika dihubungkan dengan konsep akuntabilitas, maka koperasi sudah memberikan pertanggungjawabannya kepada anggota yang sekaligus menjadi nasabah koperasi berdasarkan laporan per bulan berisi laporan pinjaman atau piutang dan setoran nasabah koperasi. Hanya saja laporan tersebut belum disusun berdasarkan standar akuntansi keuangan.

\section{SIMPULAN}


Akuntabilitas KSP "KARYA MANDIRI" Selong melalui penyusunan laporan keuangan belum optimal yang ditunjukkan dengan penyusunan laporan keuangan hanya berupa laporan per bulan berisi laporan pinjaman atau piutang dan setoran nasabah koperasi. Hal tersebut dikarenakan pemahaman pengurus tentang SAK ETAP masih kurang. Harapannya untuk masa yang akan datang KSP "KARYA MANDIRI" Selong dapat menyusun laporan keuangan sesuai standar akuntansi keuangan agar akuntabilitasnya tetap terjaga dan kepercayaan anggota meningkat.

\section{DAFTAR PUSTAKA}

Anonim, 2012, Undang-Undang RI No. 17 tentang Koperasi

IAI, Standar Akuntansi Keuangan Entitas Tanpa Akuntabilitas Publik

Jusup,Al Haryono, 2012. "Dasar-Dasar Akuntansi-Jilid 1".Yogyakarta: TIE YKPN Kusnandi Hendar, 2005. " Ekonomi Koperasi" Edisi kedua, Jakarta.

Nikita, Putri Dian, 2017. "Akuntabilitas Pengelolaan Keuangan Masjid Di Kota Mataram"', Skripsi, Fakultas Ekonomi Dan Bisnis, Universitas Mataram Rasul, Syahrudin, 2003. "Pengintegrasian Sistem Akuntabilitas Kinerja dan Anggaran dalam Perspektif UU NO. 17/2003 Tentang Keuangan Negara". Jakarta: PNRI 
B. Anggun Hilendri L. : Akuntabilitas Koperasi Melalui Laporan Keuangan 